\title{
A STUDY OF THE RENAL CIRCULATION, TUBULAR FUNCTION AND MORPHOLOGY, AND URINARY VOLUME AND COM- POSITION IN DOGS FOLLOWING MERCURY POISONING AND TRANSFUSION OF HUMAN BLOOD ${ }^{1}$
}

\author{
By HADLEY L. CONN, JR.,2 LEE WILDS, AND JOHN HELWIG WITH THE TECHNICAL \\ ASSISTANCE OF PHYLLIS IBACH \\ (From the Department of Medicine, University of Pennsylvania Medical School, and Hospital of \\ the University of Pennsylvania, Philadelphia, Pa.)
}

(Submitted for publication August 3, 1953; accepted January 12, 1954)

Many recent publications incriminate some alteration in the renal circulatory bed as a primary factor in the production and/or maintenance of most states of acute renal insufficiency (1-13). On the one hand, measurements of renal blood flow made by use of the Fick principle either at the onset of the injury or subsequent to an ensuing anuric or oliguric period have shown a significant renal ischemia associated with surgical and hemorrhagic shock, abortion, incompatible blood transfusions, heavy metal poisoning, hemoglobin infusions, and carbon tetrachloride poisoning (1-11). The accuracy of some of these measurements is open to question because of the almost negligible renal extraction of the test substance involved and the difficulties of urine collection during severe oliguria. However, this body of data has been interpreted as indicating that an initial renal ischemia is primarily responsible for the development of renal insufficiency and ultimately anuria produced by all insults not directly nephrotoxic; and that renal ischemia probably is present throughout the period of anuria whatever the initial cause. On the other hand, Trueta Raspall (12), using the results of rabbit experiments, has proposed that the important vascular abnormality is an intrarenal "juxtamedullary shunting" of blood presumably with a normal over-all flow. The continuation of this "shunting" throughout the period of renal inadequacy is implied.

Since the "shunt" hypothesis has been widely challenged and the other not yet entirely documented, consideration of these concepts raises cer-

1 This work was supported in part by the National Heart Institute of the U. S. Public Health Service (H 405) and in part by a University of Pennsylvania Faculty Research Grant.

2 Research Fellow of the American Heart Association during the tenure of this study. tain related questions: 1) Do intrarenal shunts in the intact subject ever play any part in the development or continuation of renal insufficiency states? 2) Does an initial renal ischemia persist to become a major contributor to the continuation of renal insufficiency or to the commonly associated anuria? With the development of a gas diffusion method for measuring renal blood flow which does not require urine for analysis (14) and with the application of newer arteriographic techniques, more direct and more satisfactory answers can now be given to these questions.

In the absence of readily available clinical material, two abnormal conditions which might simulate those leading to acute anuria in humans were created in dogs: bichloride of mercury poisoning and an incompatible blood transfusion reaction. Then at the time of anticipated maximal urinary suppression, the renal circulatory behavior and tubular function were studied by correlating measurements of renal blood flow, intrarenal distribution of flow, renal para-amino-hippurate (PAH) extraction, and renal arteriovenous oxygen differences with urinary and post mortem renal morphological changes.

\section{METHODS}

The two methods of producing renal or urinary tract abnormalities were: administration of human blood by transfusion, and mercuric chloride poisoning. To simulate human incompatible blood transfusion reaction, the administration of human blood rather than dog blood was resorted to. This was done despite the heterologous nature of the infusion because homologous transfusions in the dog given without regard to blood types have never been noted to cause renal damage. Mercuric chloride was chosen in light of its known ability to cause human anuria. The dosages to be given were decided as follows: the volume of human blood used was that calculated as being equivalent to transfusing $500 \mathrm{ml}$. of whole blood into an average adult human, and the amount of mercury given 
was that found to cause the greatest renal damage without consistently killing or excessively "shocking" the dog before the studies could be done.

In all, 21 dogs were used. Ten were given $7.5 \mathrm{ml}$. per $\mathrm{Kg}$. of human blood intravenously 48 to 72 hours previous to the study, while two were given the same dose two and one-half weeks previous to the study and the dose repeated three days previous to the study. Blood of all types secured from a hospital blood bank was used 10 to 15 days after its donation. Control studies were done on all dogs given human blood. Eight dogs were given 15 $\mathrm{mg}$. per $\mathrm{Kg}$. and one, $30 \mathrm{mg}$. per $\mathrm{Kg}$. of mercuric chloride by the intramuscular route.

In preparation for the renal studies, all animals were lightly anesthetized by an intravenous injection of equal parts of Pentobarbital Sodium and Dial-Urethane, 0.3 to $0.4 \mathrm{ml}$. per $\mathrm{Kg}$. A No. 8, curved tip, woven venous catheter was then passed under fluoroscopic guidance from the external jugular vein deep into the renal vein (usually the left), so that the tip lay within the shadow of the renal parenchyma. The left renal vein was used because of previous anatomical studies in dogs which showed the segment of renal vein from the renal parenchyma to the spermatic vein on the left to be consistently longer than the entirety of the right renal vein. Thus, the possibility was minimized of including in the sample, blood other than renal venous blood.

Renal venous blood was then collected through a manifold system (15). Arterial blood was obtained via a plastic catheter passed through the femoral artery into the aorta, the tip lying superior to the renal artery. This catheter was also connected to a manifold system.

Renal blood flow was measured by the gas diffusion method utilizing nitrous oxide. This principle and this specific method have both been described elsewhere in detail $(14,15)$. Flow is expressed in $\mathrm{ml}$. per $100 \mathrm{Gm}$. of renal tissue per minute.

Intrarenal distribution of flow was determined by injecting (in approximately one second) $20 \mathrm{ml}$. of 70 per cent Iodopyracet into the arterial catheter and taking seven successive radiographs of the kidneys usually 1,2 , $3,4,10,20$, and 30 seconds after the injection.

Mean arterial blood pressure was measured by a mercury manometer connected with the arterial cathetermanifold system. Renal resistance was calculated in $\mathrm{mm}$. $\mathrm{Hg}$ per ml. per $100 \mathrm{Gm}$. per min. from the renal flow and the mean arterial pressure. No correction for venous pressure was employed.

Simultaneous arterial and venous samples for oxygen content were drawn into oiled, heparinized $10 \mathrm{ml}$. syringes and were analyzed manometrically after the method of Van Slyke and Neill (16). The results were corrected for renal arteriovenous hematocrit differences, the largest correction being 3 per cent of the oxygen content. Oxygen consumption was calculated in $\mathrm{ml}$. per $100 \mathrm{Gm}$. of renal tissue per minute. The hematocrits were determined by centrifugation of samples placed in Wintrobe tubes and spun for 30 minutes at $4000 \mathrm{rpm}$. in a General Electric size 2 centrifuge.
PAH measurements were done on whole blood. The reason for the use of whole blood determinations, as well as the details of the method involved with the following exception, have been described elsewhere (17). Trichloracetic acid ( 3 per cent in final solution) was used for protein precipitation in place of cadmium sulfate, since its use resulted in more consistent and essentially complete PAH recoveries. As compared with 85 to 90 per cent renal plasma $\mathrm{PAH}$ extraction $\left(\mathrm{E}_{\mathrm{PAH}}\right)$, whole blood extractions were found to be somewhat lower (74 \pm 8 per cent), presumably due to slower diffusion of $\mathrm{PAH}$ from the red cells.

Blood urea nitrogen was determined in one animal. The amount of urine, if present, was measured, specific gravity determined, and the urine was examined microscopically and tested for albumin.

After the animals were sacrificed, the kidneys were weighed and the weight expressed in $\mathrm{Gm}$. per $\mathrm{Kg}$. of dog weight. The kidneys were then examined both grossly and microscopically.

\section{RESULTS}

\section{Human blood (Table I)}

During the initial administration of blood at a rate of approximately $3 \mathrm{ml}$. per minute, a fall in blood pressure invariably occurred after 10 to 35 $\mathrm{ml}$. This hypotension varied markedly in degree and duration. In animals being given a first infusion, mean systemic pressure falls of 40 to 100 $\mathrm{mm}$. of mercury were observed for periods from 15 minutes to an hour. This phenomenon could be repeated once or twice, but thereafter, the systemic pressure stabilized or tended to rise when the infusion was continued. In the two dogs given a second infusion, the fall in pressure was 60 to 90 $\mathrm{mm}$. of mercury and this was sustained for three hours in one, and over five hours in the other. Unfortunately, renal hemodynamics were not evaluated at this time.

Three of the dogs, including the one which had the longest period of hypotension after a second blood infusion, died before the subacute renal circulatory changes could be determined. Six which were given only a first infusion of blood, showed no evidence of renal abnormality when studied by the techniques described herein at the prescribed 48 to 72 -hour period. A complete recapitulation of the data on these animals is therefore excluded from the present report, leaving only the results in the three in which a definite renal effect was demonstrated. These three animals were designated 
TABLE I

The effects of the intravenous administration of human blood on the renal circulation, tubular function, urinary volume and composition, and renal morphology of the dog

\begin{tabular}{|c|c|c|c|c|c|c|c|c|c|}
\hline $\begin{array}{l}\text { Experimental } \\
\text { state }\end{array}$ & Urine & $\begin{array}{c}\text { Post mortem } \\
\text { kidneys } \\
(5.8-9.0 \mathrm{Gm} . / \mathrm{Kg} .)^{*}\end{array}$ & $\begin{array}{c}\text { Renal } \\
\text { arteriog- } \\
\text { raphy }\end{array}$ & $H^{\prime}$ crit & $\begin{array}{c}\text { Mean } \\
\text { arterial } \\
\text { blood } \\
\text { pressure } \\
(100-140)\end{array}$ & $\begin{array}{c}\text { Renal } \\
\text { blood } \\
\text { flow } \\
(290-400) \dagger\end{array}$ & $\begin{array}{c}\text { Renal } \\
\text { resist- } \\
\text { ance } \\
(0.25-0.48) \ddagger\end{array}$ & $\begin{array}{l}\text { Oxygen } \\
\text { consump- } \\
\text { tion } \\
(5-9) \S\end{array}$ & $\begin{array}{l}\text { Whole } \\
\text { blood } \\
\text { PAH } \\
\text { extraction } \\
(66-82 \%)\end{array}$ \\
\hline Control $A$ & $\begin{array}{l}\text { Normal } \\
1 \mathrm{ml} . / \mathrm{min} .\end{array}$ & - & - & - & $\begin{array}{l}m m . H g \\
115\end{array}$ & $\begin{array}{c}\mathrm{ml} . / 100 \\
\mathrm{Gm} . / \mathrm{min} \\
323\end{array}$ & $\begin{array}{l}\mathrm{mm} . / \mathrm{ml} . / \\
100 \mathrm{Gm} . / \\
\min . \\
0.35\end{array}$ & $\begin{array}{c}c c . / 100 \\
\text { Gm./min. } \\
6.6\end{array}$ & $\begin{array}{l}\% \\
86\end{array}$ \\
\hline \multicolumn{10}{|l|}{$A$} \\
\hline $\begin{array}{l}7 \frac{1}{2} \mathrm{ml} . / \mathrm{Kg} . \\
\mathrm{A}+\text { blood } \\
48 \mathrm{hrs} \text {. be- } \\
\text { f ore study }\end{array}$ & $\begin{array}{l}\text { Sp. gr. } 1.008 \\
0.25 \mathrm{ml} . / \mathrm{min} . \\
\text { Proteinuria } 1+\end{array}$ & $\begin{array}{l}\text { Vessels } \\
\text { hyperemic, } \\
\text { slightly pale, } \\
\text { not swollen, } \\
7.3 \mathrm{Gm} . / \mathrm{Kg} \text {. } \\
\text { "transfusion } \\
\text { nephrosis". }\end{array}$ & Normal & 42 & 110 & 305 & 0.36 & 5.9 & 57 \\
\hline Control $B$ & $\begin{array}{l}\text { Normal } \\
\text { approx. } \\
1 \mathrm{ml} . / \mathrm{min} .\end{array}$ & - & - & - & 135 & 380 & 0.36 & 7.2 & 78 \\
\hline \multicolumn{10}{|l|}{$B$} \\
\hline $\begin{array}{l}7 \frac{1}{2} \mathrm{ml} . / \mathrm{Kg} . \\
\mathrm{AB}+\text { blood } \\
72 \mathrm{hrs} \text {. be- } \\
\text { fore study }\end{array}$ & $\begin{array}{l}\text { Sp. gr. } 1.010 \\
0.2 \mathrm{ml} / \mathrm{min} . \\
\text { Protëinuria } 1+\end{array}$ & $\begin{array}{l}\text { Pale, slightly } \\
\text { edematous } \\
9.0 \mathrm{Gm} . / \mathrm{Kg} . \\
\text { "transfusion } \\
\text { nephrosis" }\end{array}$ & $\begin{array}{l}\text { Slightly } \\
\text { prolonged } \\
\text { dye shadow. } \\
\text { Enlarged } \\
\text { kidneys }\end{array}$ & 49 & 135 & 295 & 0.46 & 5.6 & 3 \\
\hline Control $C$ & $\begin{array}{l}\text { Normal } \\
\text { approx. } \\
1 \mathrm{ml} . / \mathrm{min} .\end{array}$ & - & - & 45 & 125 & 380 & 0.33 & 6.5 & 75 \\
\hline \multicolumn{10}{|l|}{ C } \\
\hline $\begin{array}{l}7 \frac{1}{2} \mathrm{ml} . / \mathrm{Kg} . \\
\mathrm{O}+\text { blood } \\
2 \frac{1}{2} \text { weeks } \\
\text { and } 72 \mathrm{hrs} \text {. } \\
\text { before study } \\
\text { BUN-40 }\end{array}$ & Anuria & $\begin{array}{l}\text { Pale, } \\
\text { edematous } \\
\text { "transfusion } \\
\text { nephrosis" }\end{array}$ & $\begin{array}{l}\text { Prolonged } \\
\text { dye shadow. } \\
\text { Enlarged } \\
\text { kidneys }\end{array}$ & 43 & 110 & 150 & 0.73 & 4.8 & 0 \\
\hline
\end{tabular}

* Normal limits in 15 animals.

† Normal limits in 11 animals.

‡ Calculated from normal limits for B.P. and R.B.F.

$\$$ Normal limits in 11 animals.

if $74 \% \pm 8 \%$ (2 S.D.) in 12 animals.

as IA, IB, and IC; the latter being the surviving dog given a second blood transfusion. The results were as follows:

Urine. Dogs IA and IB were passing $0.25 \mathrm{ml}$. and $0.2 \mathrm{ml}$. of urine per minute, respectively. The urinary specific gravity was 1.008 to 1.010 with slight proteinuria. Dog IC was anuric.

Circulatory bed. In dogs IA and IB, renal blood flow and renal resistance were within normal limits, the flow being slight ( 5 and 22 per cent), but not significantly less than the control values. Dog IC had a renal blood flow of approximately 40 per cent of normal with an elevated renal vascular resistance. The intrarenal distribution of flow was normal in all, although the prolonged parenchymal dye shadow suggested reduced total flow. Compare the renal arteriogram from a normal dog (Figure 1) with that of dog IC (Figure 2).

Revial function. Renal whole blood PAH extraction $\left(E_{\mathbf{P A H}}\right)$ fell from 86 to 57 per cent in dog IA, 78 to 3 per cent in dog IB, and 73 to 0 per cent in dog IC. The oxygen consumption remained within normal or borderline normal limits in all three animals. However, the results represented a decrease from the control values in each case. The blood urea nitrogen in dog IC was elevated 


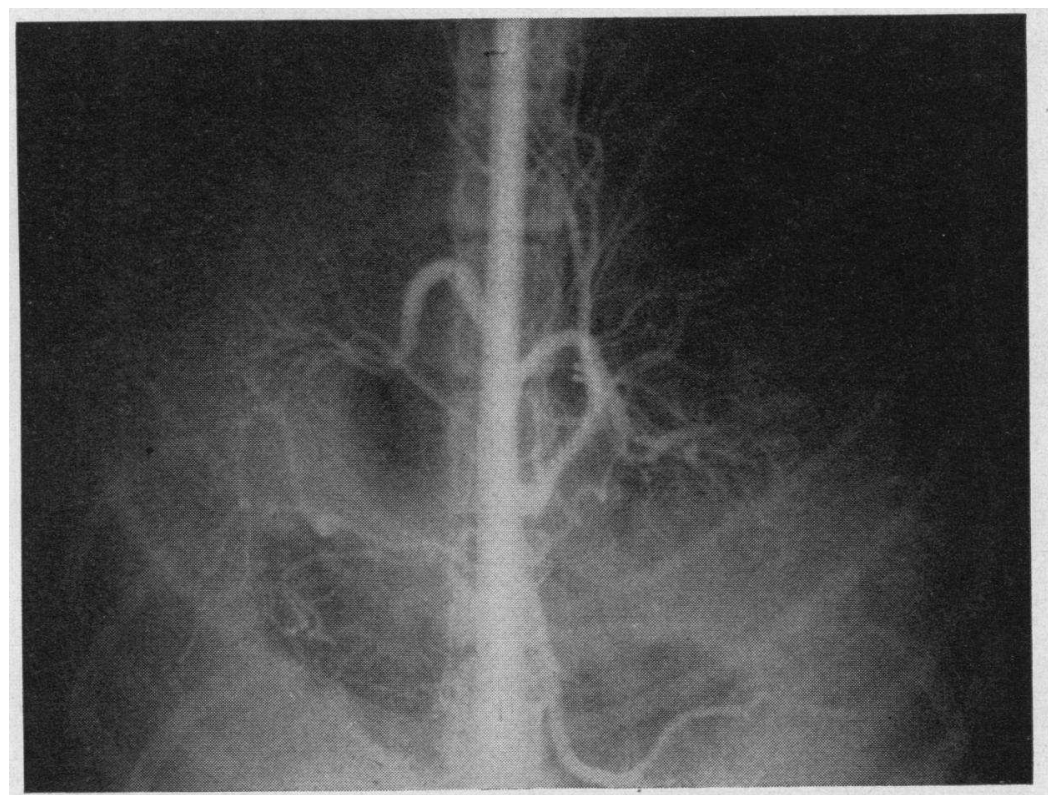

A

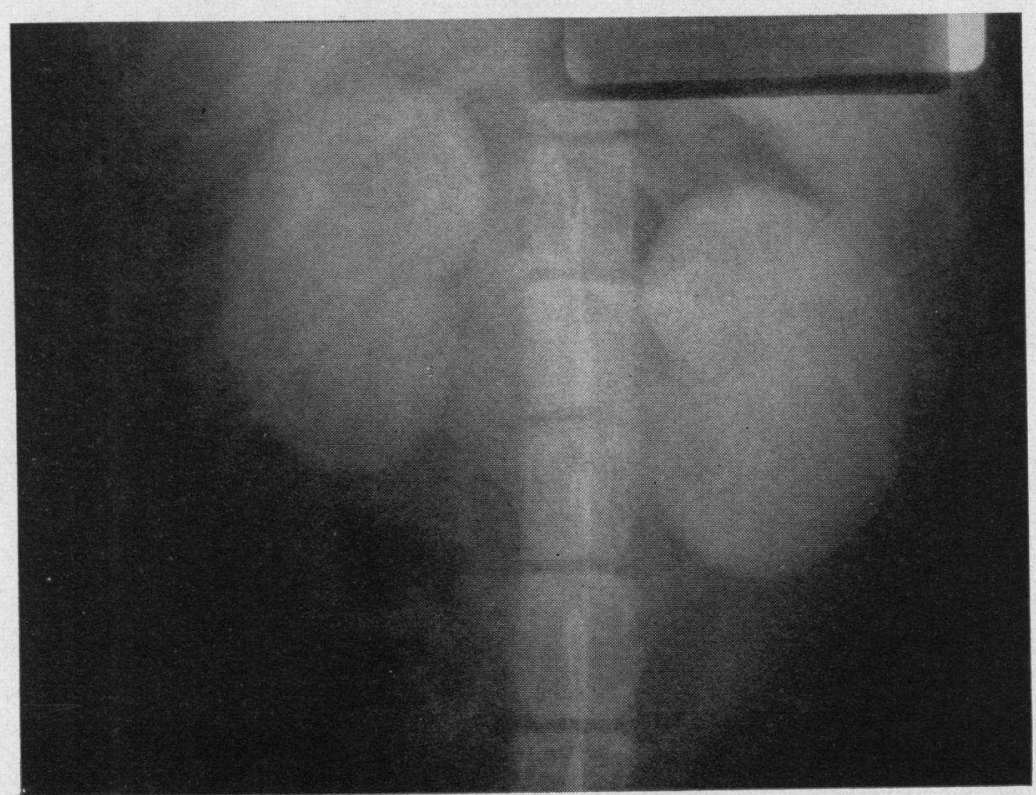

B

Fig. 1. Renal Arteriogram of a Normal Dog

Following injection of $20 \mathrm{ml}$. of 70 per cent Iodopyracet into the aorta through a polyethylene catheter (see Methods), the main renal arterial tree is filled with dye at two seconds (A) and the cortex is diffusely filled with dye at eight seconds (B).

to $40 \mathrm{mg}$. per cent. Unfortunately, this measurement was not made in the other two animals.

Post mortem examination. The tubular degeneration and necrosis associated with hemo- globin casts in the tubular lumina which have been described as characteristic of "mismatched transfusion nephrosis" were present to a moderate degree in dog IA and in large degree in dogs IB 


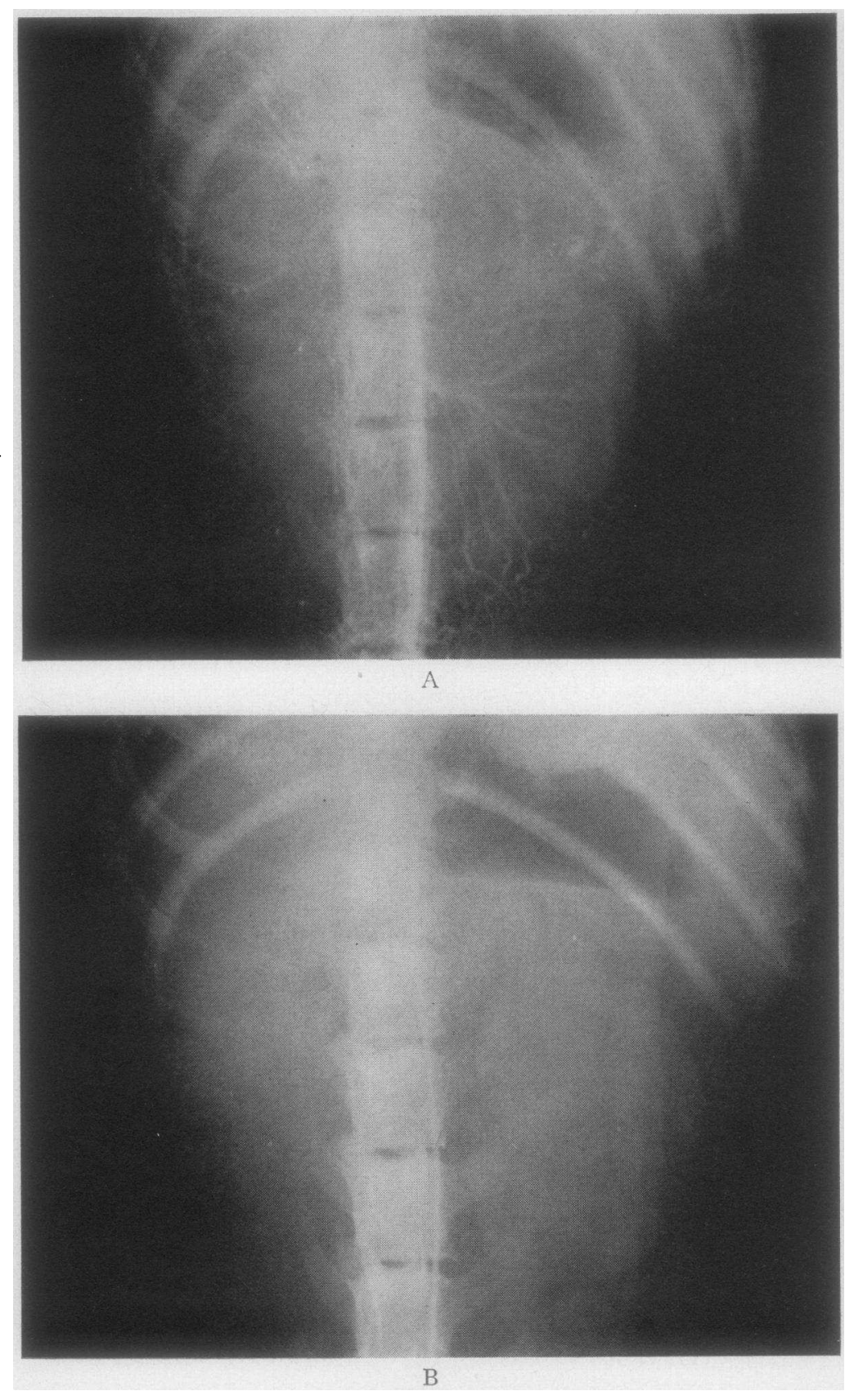

Fig. 2. Renal Arteriogram of Dog IC Seventy-Two Hours after the Administration of Human Blood

The renal vessels are normally visualized at two seconds and the dye appears equally distributed throughout the cortex at ten seconds. The right kidney, partially obscured by the rib cage, is reproduced poorly in the photograph. The left appears somewhat enlarged.

and IC. The picture seemed to represent a conglomeration of patchy changes rather than involvement of any one anatomical part of the nephron. Degenerative swelling, renal edema, and inflammatory reaction were much more in evidence in $\operatorname{dog}$ IC. 
II. Mercury bichloride poisoning (Table II).

Nine animals were given mercury bichloride; five died from the extrarenal effects before studies were made. The surviving four all showed to a varying extent: dehydration, weakness, lethargy, and bloody diarrhea. The following renal data were obtained in these animals :

Urine. Dogs IIA and IID were passing relatively normal amounts of urine $(0.5$ to $1.0 \mathrm{ml}$. per min.) 60 and 54 hours, respectively, after the mercurial injection. Dog IIC was anuric 72 hours after the injection. Dog IIB, while showing little decrease in urinary volume after 48 hours, had become severely oliguric after 12 hours. All dogs passing urine had hyposthenuria with albumin and casts.

Circulatory bed. The renal blood flow was normal in the two dogs showing little or no urinary

TABLE II

The effects of intramuscularly injected mercuric chloride on the renal circulation, tubular function, urinary volume and composition, and renal morphology of the dog

\begin{tabular}{|c|c|c|c|c|c|c|c|c|c|}
\hline $\begin{array}{c}\text { Experimental } \\
\text { state }\end{array}$ & Urine & $\begin{array}{c}\text { Post mortem } \\
\text { kidneys } \\
(5.8-9.0 \mathrm{Gm} . / \mathrm{Kg} .)^{*}\end{array}$ & $\begin{array}{l}\text { Renal } \\
\text { arteriog- } \\
\text { raphy }\end{array}$ & H'crit & $\begin{array}{c}\text { Mean } \\
\text { arterial } \\
\text { blood } \\
\text { pressure } \\
(100-140)\end{array}$ & $\begin{array}{c}\text { Renal } \\
\text { blood } \\
\text { flow } \\
(290-400) \dagger\end{array}$ & $\begin{array}{c}\begin{array}{c}\text { Renal } \\
\text { resist- } \\
\text { ance } \\
(0.25-0.48) \ddagger\end{array}\end{array}$ & $\begin{array}{c}\text { Oxygen } \\
\text { consump- } \\
\text { tion } \\
(5-9) \S\end{array}$ & $\begin{array}{l}\text { Whole } \\
\text { blood } \\
\text { PAH } \\
\text { extraction } \\
(66-82 \%) \|\end{array}$ \\
\hline & & & & & $m m . \mathrm{Hg}$ & $\begin{array}{c}m l . / 100 \\
G m . / m i n\end{array}$ & $\begin{array}{c}\operatorname{mm} . / \mathrm{ml} . / \\
\text { min. }\end{array}$ & $\begin{array}{c}c c . / 100 \\
G m . / m i n\end{array}$ & $\%$ \\
\hline $\begin{array}{l}15 \mathrm{mg} . / \mathrm{Kg} . \\
\text { (IM)- } \mathrm{HgCl}_{2} \\
60 \text { hrs. before } \\
\text { study }\end{array}$ & $\begin{array}{l}\text { Sp. gr. } 1.014 \\
\text { Oliguria } \\
\text { minimal } \\
0.4 \mathrm{ml} . / \mathrm{min} .\end{array}$ & $\begin{array}{l}\text { Grossly } \\
\text { normal } \\
\text { No micro- } \\
\text { scopic } \\
7.1 \mathrm{Gm} . / \mathrm{Kg} .\end{array}$ & - & 一 & 125 & 355 & 0.37 & - & - \\
\hline \multicolumn{10}{|l|}{$B 1$} \\
\hline $\begin{array}{l}30 \mathrm{mg} . / \mathrm{Kg} . \\
\text { (IM)- } \mathrm{HgCl}_{2} \\
48 \mathrm{hrs} . \text { before } \\
\text { study }\end{array}$ & $\begin{array}{l}\text { Sp. gr. } 1.011 \\
++ \text { albumin } \\
\text { and casts }\end{array}$ & - & 一 & 44 & 115 & 265 & 0.43 & 7.1 & 57 \\
\hline \multicolumn{10}{|l|}{$B 2$} \\
\hline $\begin{array}{l}\text { Same dog at } \\
120 \text { hrs. }\end{array}$ & $\begin{array}{l}\text { Extreme } \\
\text { oliguria } \\
\text { (occ. drop) } \\
++++ \text { al- } \\
\text { bumin and } \\
\text { casts }\end{array}$ & $\begin{array}{l}\text { Gross-slight } \\
\text { swelling \& } \\
\text { pallor } \\
\text { Micro-mod. } \\
\text { tubular deg. } \\
\& \text { necrosis } \\
8.4 \mathrm{Gm} . / \mathrm{Kg} .\end{array}$ & $\begin{array}{l}\text { Normal } \\
\text { distribution } \\
\text { Prolonged } \\
\text { cortical dye } \\
\text { shadow }\end{array}$ & 65 & 120 & 170 & 0.70 & 3.4 & 15 \\
\hline \multicolumn{10}{|l|}{$C$} \\
\hline $\begin{array}{l}15 \mathrm{mg} \cdot / \mathrm{Kg} . \\
\text { (IM)- } \mathrm{HgCl}_{2} \\
72 \mathrm{hrs} . \text { before } \\
\text { study }\end{array}$ & Anuric & $\begin{array}{l}\text { Grossly } \\
\text { normal } \\
\text { Micro- } \\
\text { marked } \\
\text { tubular de- } \\
\text { struction } \\
\text { deg. and } \\
\text { necrosis } \\
7.3 \mathrm{Gm} . / \mathrm{Kg} .\end{array}$ & Normal & 36 & 73 & 155 & 0.47 & 1.0 & 5 \\
\hline \multicolumn{10}{|l|}{$D$} \\
\hline $\begin{array}{l}15 \mathrm{mg} \cdot / \mathrm{Kg} . \\
\text { (IM)- } \mathrm{HgCl}_{2} \\
54 \text { hrs. before } \\
\text { study }\end{array}$ & $\begin{array}{l}\text { Sp. gr. } 1.007 \\
0.5 \mathrm{ml} . / \mathrm{min} \text {. } \\
++++ \text { al- } \\
\text { bumin and } \\
\text { casts }\end{array}$ & $\begin{array}{l}\text { Grossly } \\
\text { normal } \\
6.2 \mathrm{Gm} . / \mathrm{Kg} . \\
\text { Micro- } \\
\text { similar } \\
\text { to Dog C }\end{array}$ & - & 51 & 118 & 400 & 0.30 & 2.0 & 4 \\
\hline
\end{tabular}

* Normal limits in 15 animals.

+ Normal limits in 11 animals.

† Calculated from normal limits for B.P. and R.B.F.

Normal limits in 11 animals.

II $74 \% \pm 8 \%$ (2 S.D.) in 12 animals. 
volume change and was only slightly subnormal in $\operatorname{dog}$ IIB when first studied. However, at the time when urinary volume was essentially nil in dog IIB and in dog IIC, renal blood flow was only approximately 40 to 50 per cent of normal. Intrarenal distribution of blood flow, as determined by arteriography, was normal in all cases studied. The calculated renal resistance was within top normal limits in all studies except in the case of the second study on dog IIB. Here with a blood flow approximately 50 per cent normal ( $170 \mathrm{ml}$. per 100 Gm. per min.) and an associated mean pressure of $120 \mathrm{~mm} . \mathrm{Hg}$, the calculated mean resistance was 50 per cent above normal. The hematocrit, however, had increased from 44 to 65 . Only anuric dog IIC had a mean pressure at shock levels 73 $\mathrm{mm} . \mathrm{Hg}$.

Tubular function. Both oxygen consumption and $\mathrm{PAH}$ extraction were markedly reduced in the three dogs so studied except the first study on IIB where clearly abnormal values were not demonstrated. This reduction occurred in roughly parallel fashion, $\mathrm{E}_{\mathbf{P A H}}$ varying from 5 to 20 per cent normal and oxygen consumption from 20 to 65 per cent normal.

Post mortem examination. The kidneys showed widespread tubular degeneration and necrosis with scattered, minute deposits of calcium. The proximal convoluted tubules were most involved. In many areas only tubular outlines remained recognizable and the tubular lumen was obliterated. The severity of the morphological changes was well-correlated with the degree of reduction in $\mathrm{PAH}$ extraction and oxygen consumption, but not with the urine volume.

\section{DISCUSSION}

These studies show that mercury bichloride in the dosage employed here will consistently produce severe renal tubular damage in the $\mathrm{dog}$, and that initial transfusions of human blood will occasionally do so. They also suggest that appropriately timed second transfusions are much more likely to produce renal damage than the first, a view supported by other data $(17,18)$. Although the microscopic morphology indicated a difference in location and intensity of the damage caused by blood as opposed to that caused by mercury (in agreement with Oliver's hypothesis [1]), all affected animals from both groups had developed a similar functional impairment in regard to $\mathrm{PAH}$ extraction and inability either to make urine or to concentrate it. The very low renal oxygen consumption found after mercury poisoning can be attributed to the widespread tubular necrosis and marked degeneration of the non-necrotic epithelium, while the nearly normal values found following the human blood infusions can be attributed to a less massive necrobiosis and to a prominent increase in the number of leukocytes in the interstitial tissues.

These studies also show that at a time two or three days after the initial injury, marked renal circulatory derangements are not necessarily a concomitant of the tubular damage produced either by mercury or by human blood. In fact, a marked circulatory derangement was found only in two out of four animals given mercury and in only one out of three developing tubular impairment from human blood. When present, the circulatory abnormality was a reduction of renal blood flow to approximately one-half normal or less without any suggestion of alteration in the corticomedullary flow pattern. Indeed, no evidence of functioning intrarenal shunts was found in any of the animals.

The reductions in renal blood flow were not nearly so great as those reported by Bull, Joekes, and Lowe (6) in human anurics just before or after the anuric period. Their data, obtained by using the Fick method, indicated renal blood flows of from 0 to 20 per cent of normal.

The immediate factors responsible for the occurrence of renal ischemia in the two animals developing it after bichloride of mercury injections appeared to be dehydration and "shock level" blood pressure in dog IIC and severe dehydraticn with extreme hemoconcentration in dog IIB. Renal edema, which has been implicated as a cause of renal ischemia and anuria (19-21), was minimal in the dogs given mercury, but its presence was more obvious in the dogs given blood, particularly in $\operatorname{dog}$ IC. In this dog, severe renal edema was noted and was the only obvious factor on which blame could be laid for the presence of renal ischemia.

Finally, the studies show that in regard to the two experimental abnormalities produced herein. the urinary finding of extreme oliguria or actual anuria can be much better correlated with the 
presence of renal circulatory impairment than with the presence or extent of tubular damage. The three dogs (IC, IIB, IIC) making little or no urine, were the same ones found to have moderately severe renal ischemia, while all the remaining dogs had a fair to good urinary minute volume and an essentially normal renal circulation. On the other hand, the demonstrated abnormalities in tubular function and morphology were almost identical in dogs IB and IC given human blood and also, in dogs IIB and IIC given mercury; yet the urinary minute volume in the former of each group was only moderately decreased, whereas it was nil in the latter of each group. Some years ago, it was stated (22) that the development of anuria following mercury bichloride poisoning was the result of complete loss of tubular impermeability with resultant glomerular filtrate-blood iso-osmotic equilibration. The presence of an essentially normal urinary volume (and renal circulation) in dog IID, having histological evidence of tubular necrosis quite as marked (see Figure 3 ) as that found in anuric dog IIC, suggests that filtrate-blood iso- osmotic equilibration is not the most important factor involved. Tubular luminal obstruction by casts and detritus has also been implicated as a cause of anuria by many authors including Maluf (23), Oliver (24), and Harrison, Bunting, Ordway, and Albrink (25). As judged from our sections prepared by routine histological technique, admittedly inferior to individual nephron dissection, there was moderate luminal obstruction in the kidneys subjected to mercuric chloride and minimal obstruction in the kidneys subjected to human blood. Of perhaps more significance was the finding of little or no recognizable difference in this respect between the kidneys of the urinating and those of the anuric dogs.

This combination of findings leads us to propose that anuria, when present "subacutely" in the dog following mercuric chloride injections or human blood transfusion, is not simply a direct result of severe tubular damage; but rather complete urinary suppression, as opposed to moderate oliguria, is dependent mainly on a superimposition of renal ischemia upon the existing nephron damage. The

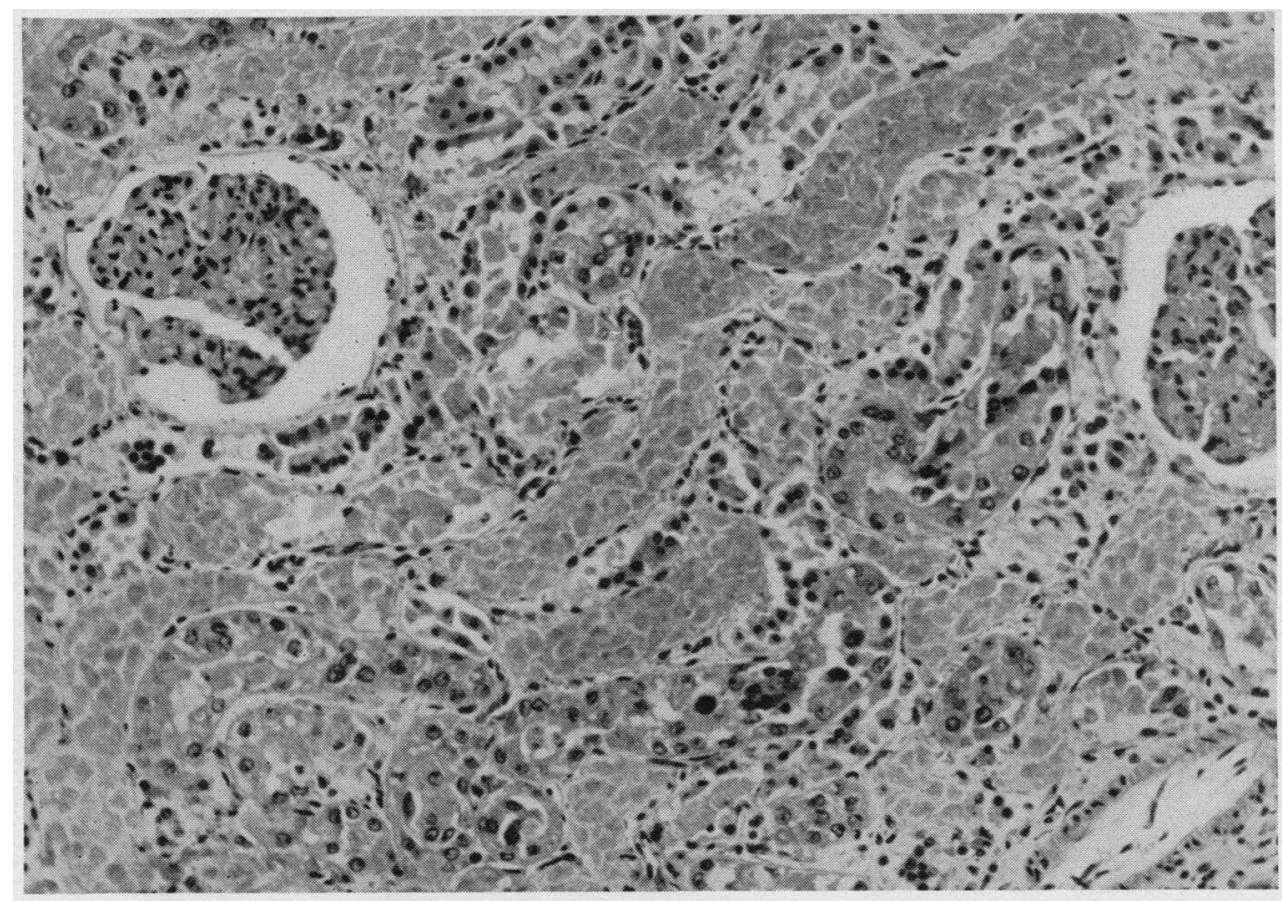

Fig. 3. Photomicrograph of Kidney of Dog IID Given Mercury Bichloride Forty-Eight Hours Previously ( $\mathrm{H} \&$ E Stain)

There is widespread tubular necrosis involving proximal tubules most severely. Note complete loss of structure with obliteration of lumina in some areas. Glomerular changes appear to be negligible. 
renal ischemia may in turn be due, not directly to tubular damage, but to such sequelae thereof as renal edema or cast obstruction or it may result from such systemic derangements as shock or dehydration.

\section{SUM MARY}

1. The effects of intramuscular mercuric chloride injection and transfusions of human blood on renal tubular function, renal circulation, urinary volume and composition, and renal morphology in the dog were studied two to four days after the initial stimulus.

2. Mercuric bichloride consistently produced renal tubular damage, while human blood produced renal tubular damage occasionally after a first transfusion and in the only dog surviving a repeated transfusion.

3. Anuria was present in two out of four surviving animals having renal damage due to mercury poisoning, and one out of three having damage following human blood transfusion.

4. The renal circulation was essentially normal in all animals, save the anuric ones in which renal blood flow was reduced to 50 per cent of normal or less. As judged by renal arteriography, no functioning intrarenal shunts were present in any of the animals.

5. It is proposed that in the present experiments, the occurrence in three animals of anuria rather than moderate oliguria was mainly due to the superimposition of renal ischemia upon existing tubular damage.

\section{ACKNOWLEDGMENTS}

The authors wish to express their appreciation to Dr. Carl F. Schmidt for extending to them the use of the facilities of the Department of Pharmacology during the course of these studies and to Drs. C. F. Schmidt, J. K. Clark, and F. C. Wood for constructive criticisms of the manuscript.

\section{REFERENCES}

1. Oliver, J., MacDowell, M., and Tracy, A., The pathogenesis of acute renal failure associated with traumatic and toxic injury. Renal ischemia, nephrotoxic damage, and the ischemuric episode. J. Clin. Invest., 1951, 30, 1307.

2. Phillips, R. A., Dole, V. P., Hamilton, P. B., Emerson, K., Jr., Archibald, R. M., and Van Slyke, D. D., Effects of acute hemorrhagic and traumatic shock on renal function of dogs. Am. J. Physiol., 1946, 145, 314.
3. Hesse, E., and Filatov, A., Experimentelle Untersuchungen über das Wesen des hämolytischen Schockas bei der Bluttransfusion und die therapeutische Beeinflussung desselben. I. Die Nierenfunktionsstörungen im akuten Experiment. Ztschr f. d. ges. exper. Med., 1933, 86, 211.

4. Lauson, H. D., Bradley, S. E., and Cournand, A. The renal circulation in shock. J. Clin. Invest., 1944, 23, 381.

5. Black, D. A. K., Powell, J. F., and Smith, A. F., Inulin and perabrodil clearance after alimentary hemorrhage in man. J. Physiol., 1941, 99, 344.

6. Bull, G. M., Joekes, A. M., and Lowe, K. G., Renal function studies in acute tubular necrosis. Clin. Sc., 1950, 9, 379.

7. Sirota, J. H., Carbon tetrachloride poisoning in man. I. The mechanisms of renal failure and recovery. J. Clin. Invest., 1949, 28, 1412.

8. Black, D. A. K., and Stanbury, S. W., The treatment of anuria. Brit. M. J., 1948, 2, 1101.

9. Marshall, D., and Hoffman, W. S., The nature of the altered renal function in lower nephron nephrosis. J. Lab. \& Clin. Med., 1949, 34, 31.

10. Breed, E. S., Personal communication.

11. Miller, J. H., and McDonald, R. K., The effect of hemoglobin on renal function in the human. J. Clin. Invest., 1951, 30, 1033.

12. Trueta Raspall, J., Studies of the Renal Circulation. Springfield, Ill., Charles C Thomas, 1948, p. 187.

13. Conn, H. L., Jr., Anderson, W., and Arena, S., Gas diffusion technique for measurement of renal blood flow with special reference to the intact, anuric subject. J. Applied Physiol., 1953, 5, 683.

14. Kety, S. S., and Schmidt, C. F., The nitrous oxide method for the quantitative determination of cerebral blood flow in man: theory, procedure and normal values. J. Clin. Invest., 1948, 27, 476.

15. Peters, J. P., and Van Slyke, D. D., Quantitative Clinical Chemistry. Baltimore, Williams \& Wilkins Co., 1931-32.

16. Conn, H. L., Jr., and Markley, K., Simultaneous comparison of renal blood flow as measured by the Fick principle and by the bubble flow meter. Am. J. Physiol., 1950, 160, 547.

17. Mueller, C. B., Eiseman, B., Mason, A. D., and Norman, P. T., Factors concerned in the production of renal disease following transfusion of mismatched blood. Surgical Forum, Clinical Congress of the Am. Coll. of Surgeons, 1952, 38, 460.

18. Conn, H. L., Jr., and Wood, J. C., Unpublished data. 19. Corcoran, A. C., Taylor, R. D., and Page, I. H., Acute toxic nephrosis; a clinical and laboratory study based on a case of carbon tetrachloride poisoning. J.A.M.A., 1943, 123, 81.

20. Peters, J. T., Oliguria and anuria due to increased intrarenal pressure. Ann. Int. Med., 1945, 23, 221.

21. Zollinger, H. U.,, Anurie bei chromoproteinurie. Hämolyseniere, Crush-Niere. Stuttgart, Georg Thieme, 1952, p. 138. 
22. Richards, A. N., Direct observations of change in function of the renal tubule caused by certain poisons. Tr. A. Am. Physicians, 1929, 44, 64.

23. Maluf, N. S. R., Factors inducing renal shut-down from lysed erythrocytes: an experimental study. Ann. Surg., 1949, 130, 49 .
24. Oliver, J., New directions in renal morphology: a method, its results and its future. Harvey Lectures, 1944-45, 40, 102.

25. Harrison, H. E., Bunting, H., Ordway, N. K., and Albrink, W. S., The pathogenesis of the renal injury produced in the dog by hemoglobin or methemoglobin. J. Exper. Med., 1947, 86, 339. 